\title{
Application of the DPSIR framework to the evaluation of the recreational and environmental conditions on estuarine beaches of the Amazon coast
}

Rosigleyse Corrêa de Sousa-Felix ${ }^{\mathrm{a}}$, Luci Cajueiro Carneiro Pereira ${ }^{\mathrm{b} 1}$, Wellington Nascimento Trindade ${ }^{\mathrm{c}}$, Ingrid Padilha de Souza ${ }^{\mathrm{d}}$, Rauquírio Marinho da Costa ${ }^{\mathrm{e}}$, José António Jimenez ${ }^{\mathrm{f}}$.

${ }^{a}$ Instituto de Estudos Costeiros, Universidade Federal do Pará, Alameda Leandro Ribeiro, s/n, Aldeia, 68600-000, Bragança, Pará, Brazil. Email: rosigleyse@yahoo.com.br

${ }^{\mathrm{b}}$ Laboratori d'Enginyeria Marítima, Universitat Politècnica de Catalunya BarcelonaTech, c/Jordi Girona 1-3, Campus Nord ed D1, 08034 Barcelona, Spain.. Email: cajueiro@ufpa.br.

${ }^{c}$ Instituto de Estudos Costeiros, Universidade Federal do Pará, Alameda Leandro Ribeiro, s/n, Aldeia, 68600-000, Bragança, Pará, Brazil. Email: etobio17@yahoo.com.br

${ }^{\mathrm{d}}$ Instituto de Estudos Costeiros, Universidade Federal do Pará, Alameda Leandro Ribeiro, s/n, Aldeia, 68600-000, Bragança, Pará, Brazil. Email: yndy89@hotmail.com

e Instituto de Estudos Costeiros, Universidade Federal do Pará, Alameda Leandro Ribeiro, s/n, Aldeia, 68600-000, Bragança, Pará, Brazil. E-mail: raucosta@ufpa.br

${ }^{\mathrm{f}}$ Laboratori d'Enginyeria Marítima, Universitat Politècnica de Catalunya BarcelonaTech, c/Jordi Girona 1-3, Campus Nord ed D1, 08034 Barcelona, Spain. Email: jose.jimenez@upc.edu.

\footnotetext{
${ }^{1}$ Corresponding Author: L. C. C. Pereira. E-mail address: cajueiro@ufpa.br, luci.pereira@pq.cnpq.br Permanent address: Instituto de Estudos Costeiros, Universidade Federal do Pará, Alameda Leandro Ribeiro, sn, Aldeia, 68600-000, Bragança, Pará, Brazil. Ph: 5591 34251209. Fax: 559134251593.
} 


\begin{abstract}
The present study proposes a diagnosis of the conditions and impacts on estuarine beaches of the Amazonian coast based on the application of the DPSIR (Driving Forces, Pressures, State, Impact, Responses) model, which identifies the natural and anthropogenic drivers affecting the environment. Natural drivers are related primarily to the accentuated hydrodynamic processes, high rainfall and fluvial discharge. The anthropogenic driver is related to the lack of planning for beach development. These human pressures result in a reduction in the quality of the beaches through microbiological contamination, the accumulation of garbage on the sand and in the water, sewage outfalls, and overcrowding which, combined with the intense local hydrodynamics and the lack of planning of recreational activities (zoning, warning signs, lifeguard coverage) may increase the risk of accidents for beachgoers, such as drowning, and injuries caused by motorboats, jet skis and stingrays. Despite all the problems identified, no response whatsoever was observed from the local authorities. The results of the DPSIR analysis indicate an urgent need for the implementation of beach management plans to improve the conditions of the beaches and in particular their safety, as well as identifying the obligations of the local authorities responsible for the future development of the Amazon coast.
\end{abstract}

Keywords: Recreational activities, DPSIR, estuarine beaches, Amazon littoral. 


\section{Highlights}

- Hydrodynamic energy can generate physical hazards (accidents) and erosion.

- The large number of sewage outfalls contribute to local points of contamination.

- Local human pressures have impacted the quality of the beaches.

- The numbers of visitors exceeded the established limits, mainly during flood tide.

- Appling the DPSIR no evidence was found of any practical response on the part of local authorities. 


\section{Introduction}

The natural characteristics of coastal areas attract large numbers of people, as well as private and public economic sectors, with their concomitant infrastructure, subjecting these areas to increasing anthropogenic exploitation and disturbance (Hardiman and Burgin, 2010). Given this, systematic planning and the establishment of coastal management initiatives are essential to the development of adequate and useful services. In coastal environments, beaches are considered to be strategic areas for the development of recreational activities and play an important role in the economic development of some coastal countries (Ariza et al., 2008; Mahony et al., 2009; Sardá et al., 2009).

Beaches can be either natural or artificial environments, and often have considerable ecological and recreational value. However, in many cases, a combination of natural processes and human pressures have resulted in critical environmental and social impacts on these environments in many parts of the world (Lozoya et al., 2011a). In fact, the coastal areas of major tourist destinations are subject to high levels of pressure and a wide variety of impacts (Ariza et al., 2008, 2010).

On the Amazon coast, sandy estuarine beaches are important areas for the development of recreational and touristic activities. Studies have shown that Amazon estuarine beaches are overcrowded during peak vacation period (i.e., July, and some bank holidays, mainly during the second half off the year). These beaches are located in inlets along a number of hundreds of kilometers of coastline, although only a few sites can be accessed overland due to the large coastal belt of mangrove forest, one of the largest found anywhere in the world (Bernardes et al., 2012; Kjerfve and Lacerda, 1993). The majority of these beaches are rural or semi-urban, and include both natural landscapes and areas that have been occupied without adequate planning (Szlafsztein, 2012; Cardoso et al., 2014). 
Studies on these beaches have shown that environmental problems, such as the contamination of the water by clandestine sewage outfalls and floating debris, and the contamination of the sand by solid refuse and sewage, are intensified during vacation periods. Despite this, the facilities of these estuarine beaches are precarious, and a great deal of investment will be required by the local authorities and private sector to guarantee the long-term quality of these beaches and the satisfaction of visitors (Pereira et al., 2014a, 2016). Unfortunately, the lack of adequate planning of recreational activities has contributed to a reduction in the quality of these beaches and a detailed analysis of the innumerous environmental and social problems is urgently required (Sousa et al., 2017).

To regulate new pressures or minimize current pressures, conceptual tools such as the DPSIR (Driver-Forces-Pressure-State-Impact-Responses) may be used to enhance policy and management. This study applies the DPSIR framework as an integrative tool to combine qualitative and quantitative features of the social and environmental interactions observed on estuarine beaches. This analytical framework is a diagnostic tool widely-used for the understanding of the complex interactions among social, economic and environmental components. This tool also aims to provide approaches for the quantification of the relevant variables, providing an integrated view of the status of the system. This combination may contribute to an effective management approach, by supporting decision-making and monitoring, as well as defining strategies to mitigate the degradation of systems (Gari et al., 2015; Pinto et al., 2013).

This diagnostic tool was developed by the Organization of Economic Cooperation and Development (OECD, 1993) and the European Environment Agency (EEA, 1995) for the adaptive management of Social-Ecological Systems (SESs), which are ecological systems linked intimately with and affected by one or more social systems (Anderies and Ostrom, 2004). The approach also attempts to establish causal relationships among the five categories of the framework, and has been used to assess and manage environmental 
problems in a number of countries (Lin et al., 2007; Lozoya et al., 2011b; Neto et al., 2013).

Given this, the main objective of this study was to apply to the DPSIR framework to the assessment of the environmental status of Amazon estuarine beaches that are used primarily for recreational activities. This is the first study applying the DPSIR in the Amazon coast and this analysis can contribute to the development of strategies to mitigate current impacts and avoid future environmental problems on this coast.

\section{Study Area}

The coast of Pará stretches from $350 \mathrm{~km}$ inside the mouth of the Amazon River to Gurupi Bay, a linear distance approximately $650 \mathrm{~km}$. The actual length of the shoreline is far greater, however, considering the complexity of the mouth of the Amazon, Marajó Bay, and the indented Atlantic coast between Marajó Bay and Gurupi Estuary. This vast and complex estuarine-marine system is dominated by a mangrove coast, and also encompasses extensive tidal flats, estuarine and oceanic beaches, delta, and coastal dunes, among other environments (Souza-Filho et al., 2003).

Murubira and Colares beaches are located on the eastern margin of Marajó Bay and Marudá beach on the Atlantic coast (Figure 1). The two sectors are dominated by meso(around $3.0 \mathrm{~m}$, in eastern Marajó bay) and macro-tides (4-6 m, on the Atlantic coast), with flood currents reaching more than $1.0 \mathrm{~m} \mathrm{~s}^{-1}$, and moderate wave energy ( $H_{\mathrm{s}}$ up to $\left.2.0 \mathrm{~m}\right)$, mainly during the flood and high tides (Pereira et al., 2012; Sousa et al., 2016). High energy events cause serious impacts throughout the Amazon coast and erosive processes can be observed on both semi-urban (including Marudá and Murubira) and rural beaches, where frontal dunes, mangroves and beachfronts are exposed to wave action (Sousa et al., 2016). Due to erosion, the backshore zone is greatly reduced or non-existent on the semi-urban beaches, such as Marudá and Murubira, where recreational use is limited 
during the high tide. On rural beaches (e.g., Colares), however, the backshore zone tends to be well-preserved. In the areas most protected from wave action, as at Colares, recreational use may nevertheless be limited by the presence of muddy sediments near the water's edge.

The intertidal zone is used for recreational activities (sunbathing, football, beach tennis and volleyball) primarily during the ebb tide. During the vacation peaks, overcrowding is most apparent during the flood and high tides, due to the sharp reduction in the intertidal zone area (Sousa et al., 2014, 2016). An excess of beachgoers can be observed principally on the semi-urban beaches, which is possibly due to the availability of infrastructure and better services, which may help attract larger numbers of visitors (Sousa et al., 2014, 2016). On Marudá beach, for example, the attractions include artisanal markets and concerts. During peak visitation periods, temporary services are installed on the semi-urban beaches, including chemical toilets, police kiosks and lifeguard stations (Sousa et al., 2016).

Sousa et al. (2017) showed that the Recreational Carrying Capacity of these three beaches has been impacted by the ongoing expansion of unregulated land use. There is thus a clear need for investments in strategies designed to mitigate existing socioenvironmental impacts and avoid further impacts in this coastal zone.

\section{$<$ Insert Figure 1>}

\section{Methods}

\subsection{General Framework}

The DPSIR model was used in this study as a diagnostic tool for the assessment of the environmental problems of the estuarine beaches of the Amazon coast, as well as the 
identification of the cause-effect relationships of human activities and their environmental and socio-economic consequences. The model has four steps: (1) interpretation of the drivers and pressures; (2) description of the actual state; (3) description of the impacts, and (4) assessment of the human response. The model was applied using data obtained from published studies, fieldwork, and laboratory analyses. The analysis of these data permitted the identification and selection of the principal indicators or parameters to be used in the DPSIR to characterize each one of the elements (Pressures, State and Impacts) included in the system.

Environmental and social studies have been conducted at Colares, Murubira and Marudá since 2012 (see Table 1) in different visitation levels (low and high visitation peaks). Based on the results of these previous studies, it was possible to define the principal problems related to natural processes (i.e., intense hydrodynamics) and anthropogenic impacts (unplanned beach development and recreational activities).

Table 1. Field sampling periods.

\begin{tabular}{lll}
\hline Month & Period & \\
\hline July 2012 & Weekend (Sunday) & Peak visitation \\
July 2013 & Weekend (Sunday) & Peak visitation \\
July 2015 & Weekday & Low peak visitation \\
November 2015 & Weekday & No visitation \\
January 2016 & Weekday & No visitation \\
\hline
\end{tabular}

\subsection{Data Collection and Processing}

The principal methods used to collect data and process are described below (see also Table 2). 
After identification, the drivers were divided in two categories: natural drivers, which can be assessed, but not controlled, and anthropogenic drivers, which include modifications driven by human activities that can be both assessed and controlled. In this study, natural drivers included oceanographic and climatic features, which were characterized through the monitoring of natural processes, including rainfall rates, tides, waves and topographic profiles. Anthropogenic drivers included social features related to the absence of planning for specific uses.

\subsubsection{Environmental and social pressures}

Pressures are defined as natural processes or human activities that either result in or can generate impacts on the environment, or affect the wellbeing of individuals. To evaluate these pressures, the processes or activities selected for analysis included those that may cause discomfort for beachgoers, and may entail social and environmental risks, as well as factors that can hamper the adequate planning of beach development.

\subsubsection{Assessment of environmental and social states}

To characterize natural coastal processes, rainfall rates were obtained from INMET (the Brazilian National Meteorological Institute) and were included in the analyses as a potential natural disturbance that may affect the local tourism industry. In addition, the local tides and waves were monitored with sensors, which logged measurements every 10 minutes during the 13 hours of each field campaign. Given the effects of hydrodynamics on beach profiles, topographic profiles were obtained (two on each beach) to determine the morphodynamic condition of each beach, based on the approach of Short (2006), as well as the erosion/accretion balance. These profiles stretched from either the dunes (at Colares) or the promenade (at Marudá and Murubira) to a depth of approximately $1.0 \mathrm{~m}$ at low tide. The analysis also combined the hydrodynamic and morphological features of the 
beaches to determine the potential physical hazards for beachgoers. Direct observation and informal interviews with local fishermen were used to identify the presence of hazardous animals.

Social variables were used to characterize beach use and the types of hazard focused on the level of beach use, recreational carrying capacity and beachgoer risks. To evaluate the overcrowding of the beaches during the peak vacation month of July, each one was surveyed on a Sunday. During each survey, the number of people present within a preestablished transect was counted every hour between 8 am and $6 \mathrm{pm}$. The assessment of carrying capacity was based on the model developed by Cifuentes (1992). Photographs were taken to assess whether the impact of the lack of adequate planning affects the risk of accidents for the beachgoers and fishermen. This evidence was complemented with direct observations of the presence of sewage outfalls and garbage, and informal interviews with beachgoers and fishermen during all the visits.

Hydrological data were collected in field campaigns conducted during the peak vacation period and the low season, to determine the pressures on the quality of the water derived from both human activities and natural processes. Surface water samples were collected every 3 hours during the 13 hours of each field campaign using Niskin oceanographic bottle (General Oceanics). These samples were used to determine the dissolved oxygen (DO), chlorophyll-a, dissolved inorganic nutrient, and thermotolerant coliform concentrations, as well as dissolved oxygen saturation (DO\%). In the laboratory, thermotolerant coliforms were analyzed in triplicate, as recommended in the descriptions of the analytical procedures. Resolution 274/2000 of the Brazilian National Environment Council (CONAMA) provided the criteria for the evaluation of the microbiological quality of the water (thermotolerant coliforms). DO was determined by the Winkler method, as modified by Strickland and Parsons (1968). The correlation between water temperature and salinity was used to calculate oxygen saturation rates, in accordance with the 
International Oceanographic tables. Water samples were vacuum-filtered through glassfiber filters (Milipore GF/F $0.7 \mu \mathrm{m}, 47 \mathrm{~mm}$ ), and the samples and filters were then freezedried to determine their inorganic nutrient and chlorophyll-a content. The chlorophyll-a and dissolved inorganic nutrient (DIN: dissolved inorganic nitrogen and DIP: dissolved inorganic phosphorous) concentrations were determined by spectrophotometry. The DO\%, chlorophyll-a, DIN and DIP values were used to calculate the TRIX trophic index (Vollenweider et al., 1998), to characterize the trophic status of the study beaches. The index is calculated by:

$\mathrm{TRIX}=(\log 10[\mathrm{Chl}-\mathrm{a} \times(\mathrm{DO} \%) \times \mathrm{DIN} \times \mathrm{DIP}]+k) / \mathrm{m}$

Where, $\mathrm{Chl}-\mathrm{a}=$ the concentration of chlorophyll-a, DO\% $=$ the oxygen saturation rate, DIN $=$ the concentration of dissolved inorganic nitrogen, and DIP $=$ the concentration of dissolved inorganic phosphorus, while the constants are $k=1.5$ and $m=1.2$. Based on this index, the water was assigned to one of the following classes of eutrophication: (i) $0-4$ - low; (ii) > 4-5 - medium; (iii) > 5-6 - high; (iv) > 6-10 - elevated.

\subsubsection{Assessment of impacts}

The direct and indirect effects of environmental and social variables on the development of recreational and touristic activities were evaluated, primarily in the context of their impacts on human wellbeing. In particular, the impacts on the local tourism industry were identified and evaluated, including discomfort to beachgoers, and the risks for society and the local facilities (services, infrastructure or access). 
Table 2. Summarized methods used for the analysis of each variable. The numbers $(1,2,3, \ldots .15)$ indicate the parameters selected and their respective methods, and the asterisks indicate previous studies (Sousa et al., 2016* and Sousa et al., $\left.2017^{\star \star}\right)$.

\begin{tabular}{|c|c|c|c|c|}
\hline & Indicators & Parameters & Methods & Time \\
\hline \multirow{2}{*}{$\begin{array}{l}\text { HYDRO- } \\
\text { MORPHODYNAMICS }\end{array}$} & \multirow{2}{*}{$\begin{array}{l}\text { Hydrodynamic data } \\
\text { Accretion/erosion balance }\end{array}$} & $\begin{array}{l}\text { Tides }^{1} \\
\text { Waves }^{2}\end{array}$ & $\begin{array}{l}\text { CTD }^{1} \\
\text { TWR } 2050^{1,2}\end{array}$ & $\begin{array}{l}\text { July } 2015^{1,2, \times} \\
\text { November } 2015^{1} \\
\text { January } 2016^{1}\end{array}$ \\
\hline & & Beach Profile ${ }^{3}$ & $\begin{array}{l}\text { Stadia method (Birkemeier, } \\
1981)^{3}\end{array}$, & $\begin{array}{l}\text { July } 2015^{3, *} \\
\text { November } 2015^{3} \\
\text { January } 2016^{3}\end{array}$ \\
\hline \multirow{8}{*}{ WATER/SAND QUALITY } & \multirow{7}{*}{$\begin{array}{l}\text { Trophic index and } \\
\text { bacteriological levels }\end{array}$} & Temperature and salinity ${ }^{4}$ & $\mathrm{CTD}^{4}$ & \multirow{7}{*}{$\begin{array}{l}\text { July } 2012^{4,5^{* *}, 6,7,8^{* *}, 9,10^{*, * *}} \\
\text { July } 2013^{4,5^{* *}, 6,7,8^{* *}, 9,10^{* *, * *}} \\
\text { July } 2015^{4,5,6,7,9,10^{*}} \\
\text { November } 2015^{4,5,6,7,9,10} \\
\text { January } 2016^{4,5,6,7,9,10}\end{array}$} \\
\hline & & Dissolved Oxygen ${ }^{5}$ & $\begin{array}{l}\text { Winkler method (Strickland and } \\
\text { Parsons 1968) }\end{array}$ & \\
\hline & & $\mathrm{DO} \%^{6}$ & UNESCO $(1973)^{6}$ & \\
\hline & & Chlorophyll-a ${ }^{7}$ & $\begin{array}{l}\text { Parsons \& Strickland (1963) and } \\
\text { UNESCO }(1966)^{7}\end{array}$ & \\
\hline & & Dissolved Nutrients ${ }^{8}$ & $\begin{array}{l}\text { Strickland and Parsons (1972) } \\
\text { and Grasshoff et al. (1983) }\end{array}$ & \\
\hline & & Trophic Index ${ }^{y}$ & Vollenweider et al. (1998) ${ }^{9}$ & \\
\hline & & Thermotolerant colifoms ${ }^{10}$ & APHA $(2005)^{10}$ & \\
\hline & Visual Quality & $\begin{array}{l}\text { Number of sewage outfalls }{ }^{11} \\
\text { Presence of trash }\end{array}$ & $\begin{array}{l}\text { Direct observation - counting } \\
\text { sewage outfalls }{ }^{11} \\
\text { Direct observation - presence or } \\
\text { absence }^{12}\end{array}$ & $\begin{array}{l}\text { July } 2012^{11,12_{\star, * \star}} \\
\text { July } 2013^{11,12_{\star, * \star}} \\
\text { July } 2015^{11,12_{\star}}\end{array}$ \\
\hline \multirow{3}{*}{ BEACH USE } & $\begin{array}{l}\text { Overcrowding (Carrying } \\
\text { Capacity) }\end{array}$ & Number of beachgoers ${ }^{13}$ & Adapted from Cifuentes $(1992)^{133}$ & \multirow{2}{*}{$\begin{array}{l}\text { July } 2012^{13,14 *} \\
\text { July } 2013^{13,14_{\star}} \\
\text { July } 2015^{13,14}\end{array}$} \\
\hline & Noise (Sound pollution) & $\begin{array}{l}\text { Use of sound trucks and car } \\
\text { sound systems }\end{array}$ & $\begin{array}{l}\text { Direct observation - presence or } \\
\text { absence }{ }^{14}\end{array}$ & \\
\hline & $\begin{array}{l}\text { Hazards and risks } \\
\text { (Accident risks) }\end{array}$ & $\begin{array}{l}\text { Animals, drownings, motorboats, } \\
\text { other vessels, etc. }{ }^{15}\end{array}$ & $\begin{array}{l}\text { Direct observation and informal } \\
\text { interviews }\end{array}$ & $\begin{array}{l}\text { July } 2012^{15} \\
\text { July } 2013^{15} \\
\text { July } 2015^{15}\end{array}$ \\
\hline
\end{tabular}




\subsubsection{Responses}

The response of beachgoers, the tourism sector, and the government is the end result of the unwanted impacts that affect the links between drivers, pressures, state and impacts. In fact, the combination of human activities and environmental risks makes the DPSIR a useful tool for the identification of the different measures needed to avoid specific problems. A number of measures can be implemented to mitigate these problems, and in the present study, the management measures judged necessary for the study area were compiled and assessed, given the lack of any response on the part of the local authorities.

\section{Results}

\subsection{Application of the DPSIR framework}

The DPSIR framework was used as an analytical framework to evaluate the changes in Amazonian estuarine beaches related to both natural forces and human use. The main driving forces were identified and their impacts on the system functioning were assessed (see below).

\subsubsection{Drivers}

Based on the data analysis and specific local characteristics, both natural and anthropogenic drivers were identified. Natural drivers were selected based on local oceanographic and climatic features. (i.e., high hydrodynamic energy, high rainfall levels, and the presence of adjacent river systems). The tidal range, wave heights, rainfall rates, and the presence of river discharge were studied to assess beachgoer discomfort, and the hazards/risks for services, infrastructure and society.

The absence of any systematic management strategies for beach use is the principal anthropogenic driver, and the main factor inducing the inappropriate use and occupation of the study beaches. The anthropogenic drivers were divided into three sub- 
classes: social, morphological and ecological. Social drivers were assessed in the context of local infrastructure and services, overcrowding, and the organization and planning of recreational activities. Erosion rates were considered to be a morphological driver, although they were combined with a natural driver (high hydrodynamic energy) and unplanned occupation. Water quality was identified as an ecological driver, and is a combination of both natural (high concentrations of suspended particulate matter from river discharge and mangroves) and social drivers (inadequate services, in particular, the lack of public sanitation). Data on these drivers were collected using the procedures described in Table 2.

\subsubsection{Pressures}

According to the analysis of the drivers presented above, the natural pressures include (i) hydrodynamic energy, which can generate negative impacts, physical hazards (accidents) and erosion (changes in the beach profile) on beaches when high energy conditions prevail (principally during equinoctial spring tides), whereas stingray accidents typically occur on beaches with low hydrodynamic energy; (ii) high rainfall levels, which limit the development of recreational and tourism activities, due to the duration of the rainy season (approximately six months), and (iii) high fluvial discharge associated with high hydrodynamic energy, which results in high turbidity, generating discomfort for beachgoers and affecting the local tourism industry.

In the case of human pressures, the lack of planning of beach development results in: (i) unplanned occupation of the land, which can intensify the changes in the beach profile and the erosion process, (ii) reduced investment in services and infrastructure, which impacts the quality of the beach primarily through the presence of solid waste and of illegal sewage outfalls, and (iii) lack of any beach management program, including the planning of recreational activities, which diminishes the safety of the visitors. 


\subsubsection{State}

The current state of the environment results from the equilibrium between the dynamics of natural systems and anthropogenic forces, which impact the natural conditions. The state of each study beach will be described below.

\section{- "Basic State" - Hydro/Morphodynamic}

Colares is characterized morphodynamically as a tide-dominated beach with a very gentle gradient $\left(<1^{\circ}\right)$, resulting in a $400 \mathrm{~m}$ wide intertidal zone (during low spring tides) covered by fine sand (upper intertidal zone) and mud (lower zone). During high spring tides, when tidal range is approximately $3-4 \mathrm{~m}$, the intertidal zone is covered completely and significant wave height $\left(H_{\mathrm{s}}\right)$ reaches $0.6 \mathrm{~m}$. Dunes are present in the backshore zone.

Murubira is a tide-modified beach with a steep slope at high tide, coarser sand and a steeper low tide gradient ( 5 to $8^{\circ}$ ). During neap tides, tidal range is around $3 \mathrm{~m}$ and the intertidal zone is less than $100 \mathrm{~m}$ wide during low tide. At high tide, significant wave heights $\left(H_{\mathrm{s}}\right)$ reach $0.7 \mathrm{~m}$ and the recreational activities in the intertidal zone are limited to a strip of sand $10 \mathrm{~m}$ wide.

Marudá is a tide-dominated beach with low gradient (less than $2^{\circ}$ ). The intertidal zone is more than $300 \mathrm{~m}$ wide, and covered by fine sand (upper zone) and mud (lower zone). Significant wave height $\left(H_{\mathrm{s}}\right)$ may reach almost $1.0 \mathrm{~m}$ during high tides, when the intertidal zone is covered completely by the tidal range of 5-6 $\mathrm{m}$ during spring tides.

Marudá and Murubira beaches presented erosive features (loss of more than $4 \mathrm{~m}^{3}$ $\mathrm{m}^{-1}$ ) in both beach profiles between July 2015 and January 2016. By contrast, Colares beach was characterized by a process of accretion, accumulating more than $4 \mathrm{~m}^{3} \mathrm{~m}^{-1}$ of sediments during the same six-month period. 


\section{- Water quality}

The combination of high rainfall rates (annual precipitation is typically above $2500 \mathrm{~mm}$ ) and hydrodynamic energy, together with the considerable discharge of local rivers, contributes to the high turbidity ( $>50 \mathrm{NTU}$ ) of the water on the beaches of Amazonian estuaries. This turbidity reduces the visual quality of the water, and has a negative effect on the recreational experience of beachgoers. This was further emphasized by the trophic condition of the study beaches (Figure 2). The values obtained for the TRIX index indicated that Colares and Murubira beaches were at the highest trophic level (>6).

\section{$<$ Insert Figure 2>}

The table 3 shows the thermotolerant coliform levels recorded on the beaches in relation to the limits recommended by CONAMA for different types of activity. In general, the highest thermotolerant concentrations were recorded during the vacation period (July), exceeding 1100 MPN $100 \mathrm{~mL}^{-1}$ (the limit for bathing) in $60 \%$ of the samples at Marudá beach in July 2012, when the large number of sewage outfalls may contribute to local points of contamination during this period of greater visitation. Marudá and Murubira also presented $60 \%$ of samples higher than the value recommended for fishing (1000 MPN 100 $\mathrm{mL}^{-1}$ ) during periods of greater visitation. For the other activities (navigation and indirect contact: sailing, jet ski, etc.), the samples were within the limits established by CONAMA.

The presence of innumerable illegal sewage outfalls (14 at Murubira, eight at Marudá and one at Colares) and of garbage on the sand and in the water affected the visual aspect of beach quality. 
The presence of garbage resulted in repugnant odors, primarily at Marudá and Murubira, where beach parties and public shows are frequent during the vacation period. This situation is further aggravated by the lack of public rest rooms and the irregular collection of garbage. Given this, the widespread use of disposable and nonbiodegradable products has contributed to the pollution of the waterfront. Even when the beaches are cleaned, items of small size, such as bottle caps, broken glass, nails, straws, etc., are usually overlooked, and become mixed in with the sand, representing a potentially serious hazard for beachgoers, especially children.

Table 3. Percentage of samples exceeding the recommended limit (\%) in the study months by activity (CONAMA 274/2000); ( - ) None of the samples were above the recommended limit.

\begin{tabular}{|c|c|c|c|c|c|}
\hline Activity & CONAMA Limits & Date & Murubira & Colares & Marudá \\
\hline \multirow{5}{*}{ Direct contact } & \multirow{5}{*}{$\begin{array}{l}>1100 \text { MPN } 100 \mathrm{~mL}^{-1} \text { in } \\
80 \% \text { of the samples }\end{array}$} & $\mathrm{Jul} / 12^{*}$ & $20 \%$ & $20 \%$ & $60 \%$ \\
\hline & & Jul/13* & $40 \%$ & $20 \%$ & $40 \%$ \\
\hline & & Jul/15 & $20 \%$ & $20 \%$ & - \\
\hline & & Nov/5 & $20 \%$ & - & - \\
\hline & & Jan/16 & $20 \%$ & $40 \%$ & - \\
\hline \multirow{5}{*}{ Fishing } & \multirow{5}{*}{$\begin{array}{l}1000 \text { MPN } 100 \mathrm{~mL}^{-1} \text { in } \\
80 \% \text { of the samples }\end{array}$} & $\mathrm{Jul} / 12$ & $40 \%$ & $40 \%$ & $60 \%$ \\
\hline & & $\mathrm{Jul} / 13$ & $60 \%$ & $40 \%$ & $60 \%$ \\
\hline & & Jul/15 & $40 \%$ & $40 \%$ & - \\
\hline & & Nov/5 & $40 \%$ & $20 \%$ & - \\
\hline & & Jan/16 & $20 \%$ & $60 \%$ & - \\
\hline Indirect contact & $\begin{array}{l}2500 \mathrm{MPN} 100 \mathrm{~mL}^{-1} \text { in } \\
80 \% \text { of the samples }\end{array}$ & & - & - & - \\
\hline Navigation & $\begin{array}{l}4000 \mathrm{MPN} 100 \mathrm{~mL}^{-1} \text { in } \\
80 \% \text { of the samples }\end{array}$ & & - & - & - \\
\hline
\end{tabular}

\section{- Beach use/Hazards}

Beach use include overcrowding and recreational activities, and hazard and risks. 
(i) Overcrowding and recreational activities

During the periods of peak visitation (Sundays in July), the study beaches were overcrowded in the two zones most used by beachgoers - zone 1 (promenade and backshore) and zone 2 (intertidal zone). In zone 1, the numbers of visitors far exceeded the established limits (Figure 3), especially at Marudá (1386\%) and Murubira (2360\%). This overcrowding was accentuated by the presence of sound trucks, which attract young beachgoers, in particular.

Zone 2 also exceeded recommended limits, by $185 \%$ at Marudá and $124 \%$ at Murubira. These peaks of overcrowding were determined by the flood tide, which reduced the area available in this zone drastically. The recommended numbers of beachgoers defined by Sousa et al. (2014) were 44 for zone 1 and 197 for zone 2 at Marudá, and 10 and 82, respectively, at Murubira.

During these peaks, the local infrastructure and services are totally inadequate to meet the needs of the beachgoers. The discharge of domestic effluents and the discarding of garbage also increase during these periods. At Murubira, the sound pollution caused by car sound systems disturbs many beachgoers, despite local laws and the existence of warning signs announcing the legal limits.

\section{$<$ Insert Figure 3>}

(ii) Hazards and risks

The lack of zonation for recreational activities, the absence of warning signs, and the inadequate number of lifeguards all contribute to the presence of hazards and the risk of 
accidents on the study beaches. Drownings occur on all the beaches, while accidents provoked by motorboats and jet skis are common at Colares and Murubira, and by kitesurfing at Marudá. Accidents by stingrays also occur principally at Colares.

An intertidal channel may be formed during periods of increased hydrodynamic energy, represented a risk for the elderly and young children, as observed at Colares. This beach is ideal habitat for stingrays, which represent a considerable risk to both beachgoers and fishermen, given the reduced wave energy.

At both Marudá and Murubira, flood tide rises very quickly (in 4-5 h) causing problems for both the elderly and young children, especially when maximum wave heights exceed $1 \mathrm{~m}$. The long distance between the dry sand and the water's edge at low tide (100-400 m) also represents a risk for beachgoers.

The existence of the Barreiras Formation at Murubira and Colares also resulted in the presence of rock fragments on the beach, which can result in a substantial risk of accidents for beachgoers.

\subsubsection{Impacts}

Impacts are the consequences of changes in both natural and anthropogenic states. The principal impacts (Figure 4) recorded during the peak vacation period were:

(i) Erosion: changes resulting in a reduction of the beach profile, degradation of dune fields and mangroves, damage or destruction of the infrastructure of the promenade;

(ii) Hydrodynamics: strong hydrodynamic energy, creating the potential for accidents (e.g., drowning) and the transportation of floating debris, which affects beach quality;

(iii) Water quality (pollution through the discharge of waste water onto the beach): affects the use of water for bathing, and impacts the development of other 
economic activities such as fishing (see Table 3), as well as provoking health problems in beachgoers;

(iv) Beach use (visual and sound pollution, overcrowding and the lack of planning of recreational activities): provokes discomfort in beachgoers, the reduction of the recreational capacity carrying, and an increase in the risk of accidents.

\section{$<$ Insert Figure 4>}

\subsubsection{Response}

In the case of the response of society to the situation, the results of the present study show that the problems in the study areas have grown in response to increasing anthropogenic pressures related directly or indirectly to the development of local tourism. In particular, the problems are related to: (i) the reduced investment in services and infrastructure, which results in impacts such an increase in the production of sewage and solid refuse, (ii) the unplanned occupation of land, in particular in vulnerable environments, such as dunes and mangroves, which can lead to their total destruction, and (iii) a lack of planning or controls to regulate recreational activities.

Despite the ongoing increase in pressures and environmental impacts, no evidence was found of any practical response on the part of local authorities in terms of either environmental management or any specific measures contributing to the of sustainable development of the beaches or the administration of their environment. In fact, there has been no intervention whatsoever to mitigate or minimize either the natural or the anthropogenic impacts identified during the present study.

Specific planning for the recreational use of the coastal environment of the study area will be fundamental for the avoidance or mitigation of future impacts and guarantee 
the satisfaction of beachgoers. The monitoring of environmental indicators ${ }^{1}$ may, for example, contribute to the preventive control of the pressures and impacts resulting from natural and anthropogenic drivers. In addition to improved monitoring, investment is required in services and infrastructure (e.g., public sanitation), regulatory measures (e.g., the control of unplanned land use), and the establishment of norms and legislation that will guarantee ideal conditions for the use of the study beaches.

The Pará State Coastal Management Program (GERCO-PA) is one of the regulatory mechanisms available in the official state environment policy (State law number 5887/95), which is an integral component of the National Coastal Management Plan. The state program is still incipient, however, and unfortunately, there are no effective monitoring programs in place to provide data on the environmental quality of these beaches.

While CONAMA provides well-established criteria for the assessment of the quality of the water of beaches destined for recreational use, no public or private institution in Pará has assumed responsibility for the monitoring of these environments. In addition to the CONAMA guidelines, a number of other criteria can be used for the evaluation of the water, and guarantee the quality of the region's coastal waters, although no such criteria are applied in practice by any local authority.

The implementation of regulatory norms aimed specifically at the use of the coastal space (beach environment) and the recreational activities developed at the beaches of each of the municipalities located within the study area will be essential. The Municipal Coastal Management Plan, which is also one of the regulatory mechanisms available in the State Environmental Policy (state law 5887/95), may also provide a useful approach to the specific problems of each municipality. However, the legislative bill that will instate the state coastal management policy has yet to be approved, and until this happens, the

\footnotetext{
${ }^{1}$ Hydrological, hydrodynamic and climatological components.
} 
municipal management plan will not be put into practice. This reflects the incapacity of the local authorities, which make almost no practical efforts to devise or implement plans of coastal management for recreational activities or the sustainability of Amazon beaches.

Assuming progressive population growth, and increasing impacts from beach development and recreational activities, it is essential that the local authorities implement effective management programs that integrate the assessment of pressures and provide appropriate policies to mitigate further impacts on these well-preserved environments. The application of the DPSIR to the estuarine beaches of the Amazon coast is summarized in Figure 5.

\section{$<$ Insert Figure 5>}

\section{Discussion}

The DPSIR framework has been used widely by the managers and administrators of beach environments in various parts of the world, providing the basis for responsible decision-making as part of integrated beach management programs (Lozoya et al., 2011a). The approach adopted in the present study was intended to contribute to the development of the tourism industry of the beaches of the region of the Amazon estuary, based on the improvement of the wellbeing of beachgoers, and the application of effective policies and decision-making during future application of integrated beach management programs.

\subsection{Environmental-Social interactions and management concerns}


The current state of study area was characterized by the findings of the DPSIR analyses, which showed that this area is affected by both natural and anthropogenic pressures, which result in significant impacts. The lack of any practical response on the part of the local authorities will lead to the progressive degradation of the region's social and ecological systems.

In the Amazon, coastal areas have considerable potential for the development of recreational and touristic activities (Szlafsztein, 2012). However, adequate administrative measures will be necessary to minimize local problems, improve conditions, and provide guidelines for the planning of the management of coastal areas.

In environments where natural resources are still well preserved, as is the case of most Amazon beaches, the demand for good quality beaches and the preservation of the natural and physical features of coastal areas should be prioritized by local authorities. In this context, there has been a peak in the construction of highways and bridges in recent decades, leading to a boom in the occupation of coastal areas (Szlafsztein and Sterr, 2007).

These incentives have lacked planning, and most buildings (houses, bars, restaurants, hotels, guesthouses, and other commercial establishments) have been constructed in dune fields, mangroves and on cliffs, normally only a few meters above the high spring tide line (Oliveira et al., 2011; Pinto et al., 2011; Silva et al., 2011). The illegal and unplanned occupation of coastal areas, associated with the high local hydrodynamic energy has resulted in the destruction of natural environments, together with the infrastructure constructed in the foreshore zone. This problem is accentuated in semi-urban beaches, i.e., Marudá and Murubira (Nascimento and Lima, 2010). Similar problems have been found on other urban and semi-urban beaches on the Amazon coast (Pereira et al., 2014b; Silva et al., 2013). 
However, there have been no investments in the improvement of infrastructure or services, which also harms the quality of recreational activities on Amazon beaches (Pinto et al., 2013; Sousa et al., 2013). The lack of public sanitation, for example, is a problem found in many countries, and may result in both esthetic problems and risks to human health (Elmanama et al., 2006; Fewtrell and Kay, 2015; Praveena et al., 2013a) through the presence of thermotolerant coliforms (Praveena et al., 2013b). The invisible pathogens of these coastal waters present a potential risk for the health of local bathers (Neil et al., 2004). In the present study area, only Murubira has a sewage treatment station, although it was deactivated in 2011, and all the beaches are contaminated at specific points. While the waters are highly eutrophic, which is a typical natural characteristic of the Amazon region (Pamplona et al., 2013; Pereira et al., 2013).

In addition to the ongoing incentives for the development of the tourism industry on the coast, the local population may increase up to tenfold during vacation periods (Cabral et al., 2015), resulting in overcrowding, principally at Murubira and Marudá. The number of visitors has greatly exceeded the limits proposed by Sousa et al. (2014) for the recreational carrying capacity of the beaches, leading to the intensification of environmental problems.

In addition, the lack of planning for recreational activities can result in accident risks for beachgoers (e.g., drowning, injuries caused by motorboats, jet skis and stingrays), and the zoning of activities, the availability of warning signs, and an adequate number of lifeguards are urgently required. A similar lack of planning is observed in other sectors of the Amazon coast (Pereira et al., 2014b; Silva et al., 2013). Unfortunately, our study highlighted the lack of adequate policies or appropriate management measures provided by local government authorities. 


\subsection{Management actions and recommendations}

As mentioned in the Results, the principal driver of the environmental problems found in the study area is the lack of coastal planning. This is an important finding, given that, based on European policies, the principal focus of the DPSIR approach should be decision-making based on the evaluation of driving forces (Rovira and Pardo, 2006). In this context, the principal measure that may influence this drive is, essentially, the establishment of effective coastal management for the regulation of activities and usage (fisheries and recreation). There is also an urgent need for the creation and implementation of management programs, similar to GERCO (the Pará State Coastal Management Program), which has yet to be approved, on a municipal scale, with the participation of the relevant administrative bodies.

Then, a number of initiatives may contribute to the mitigation of the problems diagnosed during the present study, such as the installation of a system for the collection and treatment of waste water and domestic effluents, and the activation of existing sewage treatment plants. As there are no wastewater treatment plants on the Amazon coast, recreational activities can be affected by the many illegal sewage outfalls. The concentration of $E$. coli has been used as an indicator of contamination by sewage on recreational beaches around the world (Zhang et al., 2013; Fiorentino et al., 2014), given that fecal contamination has provoked millions of serious infection, and represents a major public health risk. The discharge of untreated sewage into aquatic environments is strictly prohibited in Brazil by CONAMA resolution number 357/2005 (article 24) and Pará State Law number 5887/1995 (Pará, 1995).

In this context, the local authorities must also monitor periodically the conditions of the water destined for bathing, using physical-chemical and microbiological indices. To be effective, however, it will be necessary to adapt the CONAMA criteria to the specific 
conditions of Amazonian waters (high concentrations of dissolved nutrients and high turbidity), in order to avoid the inadequate classification of water for recreational use.

An effective public cleaning system should also be established, especially during periods of maximum visitation, with daily clearing of waste from the beach at low tide. The disposal of solid waste, including plastics, paper and metal, leftover food, and human and animal excrement, directly onto the beach must be prohibited to avoid illness, injuries, visual pollution, the migration of floating debris to other areas, and user dissatisfaction. In addition to this recommendation, it will be necessary to increase the number of trash bins and public bathrooms.

Appropriate planning of land use will be essential to improve the local landscape, accommodate morphodynamic changes, avoid the destruction of natural resources (dunes, mangrove forests) and buildings, and avoid potential conflicts between local economic sectors and the natural environment. In particular, it will be necessary to restrict the construction of buildings to behind the foredune or other depositional environments, as mandated by federal law 7661/88 of the Brazilian National Coastal Management Plan.

To regulate the multiple recreational activities observed within the study area, effective coastal management measures will be essential for the mitigation or avoidance of accidents or the conflicts that may arise during the use of the beach environment, thus guaranteeing the safety and quality of the recreational activities of the beachgoers. It is well known that the presence of lifeguards and the zoning of recreational activities, such as the delimitation of swimming areas by flags, marker buoys and signs, may reduce considerably the risk of accidents and conflicts, although this will require the guidance of beachgoers, who must be alerted to the dangers of the beach environment, including maps and other information on natural and man-made risks.

These management measures are based on the beach use and safety norms adopted by many European countries, as well as the United States and Australia (such as Blue 
Flag, http://beachsafe.org.au/), and which have already been proposed for other beaches on the Amazon coast, which also lack effective management initiatives (Pereira et al., 2014a, 2016).

Overall, the DPSIR model proved be an excellent analytical tool for the evaluation of specific local scenarios through the integrated analysis of socio-environmental questions, with potential applications for other beaches in the Amazon region, which present broadly similar patterns of drivers and responses, as observed in the present study. However, as no response was detected from any local authority, the findings of the present study allow us to recommend the following mitigating measures: development and planning of recreational activities, including preventive environmental education activities for residents and visitors; environmental monitoring (hydrodynamics, morphology and quality of the water and sand); removal of sewage outfalls and construction of sewage treatment plants; an increase in the availability of public services, principally during peak visitation periods; the use of warning signs, principally to indicate areas of risk for bathers; an increase the number of lifeguards; regulation of sound pollution, and the zoning of activities (swimming, bathing, surfing).

\section{Acknowledgments}

This study was financed by Pro-Amazonas (3290/2013) and Ciências do Mar II (43/2013). The authors Sousa (141551/2012-7), Pereira (310909/2014-7 and 200629/2014-0) and Costa (309527/2014-7 and 200622/2014-5) would like to thank CNPq for research grants. Sousa would also like to thank CAPES for Ph.D sandwich grants (8337/13-6) and FADESP for translation fees (PAPQ 01/2016). We are also indebted to Stephen Ferrari for his careful correction of the English.

\section{References}


Anderies, J.M., Ostrom, E., 2004. A framework to analyze the robustness of socialecological systems from an institutional perspective. Ecology and Society, 9 (1), $18 p$.

APHA (American Public Health Association); AWWA (American Water Works Association); WEF (Water Environment Federation. Standard Methods for the Examination of Water and Wastewater. Alexandria, Virginia: Water Environment Federation, 2012, 1368p.

Ariza, E., Jimenez, J.A., Sarda, R., Villares, M., Pinto, J., Fraguell, R., Roca, E., Marti, C., Valdemoro, H., Ballester, R., Fluvia, M., 2010. Proposal for an Integral Quality Index for Urban and Urbanized Beaches. Environ. Manag. 45, 998-1013.

Ariza, E., Jiménez, J.A., Sardá, R., 2008. A critical assessment of beach management on the Catalan coast. Ocean Coast. Manag 51, 141-160.

Bernardes, M.C., Knoppers, B.A., Rezende, C.E., Souza, W.F.L., Ovalle, A.R.C., 2012. Land-sea interface features of four estuaries on the South America Atlantic coast. Braz. J. Bio. 72 (3), 761-774.

Birkemeier, W.A., 1981. Fast Accurate Two-Person Beach Survey, Coastal Engineering Technical Aid 81-11. U.S Army Engineer Waterways Experiment Station. Coastal Engineering Research Center, Vicksburg, Mississippi, USA, 22 p.

Cabral, E.R., Dias, J.S., Gomes, S.C., 2015. Gestão Ambiental em Espaços de Lazer e e Turismo: As Praias Urbanas da Amazônia Brasileira. Rev. Rosa dos Ventos -Turis. e Hospit. 7 (2), 269-28.

Cardoso, G. F., Souza Jr., C., Souza Filho, P.W.M., 2014. Using spectral analysis of Landsat-5 TM images to map coastal wetlands in the Amazon River mouth, Brazil. Wetl Ecol Manag., 22: 1, 79-92. 
Cifuentes, M. A., 1992. Determinación de capacidad de carga turística en áreas protegidas. Costa Rica: Biblioteca Orton IICA/CATIE, 28p. Available in: http://www.ulpgc.es/hege/almacen/download/23/23388/articulocifuentes.pdf.

CONAMA - Conselho Nacional de Meio Ambiente, Brasil. Resolução 274 de 29 de novembro de 2000. Dispõe sobre a qualidade das águas de balneabilidade. Diário Oficial da República Federativa do Brasil, 8 de janeiro de 2001.

EEA. European Environmental Agency, 1995. Europe's Environment: the Dobris Assessment. Copenhagen, 8p.

Elmanama, A.A., Afifi, S., Bahr, S., 2006. Seasonal and spatial variation in the monitoring parameters of Gaza Beach during 2002-2003. Environ. Res. 101, 25-33.

Fewtrell, L., Kay, D., 2015. Recreational Water and Infection: A Review of Recent Findings. Current Environ. Health Rep. 2, 85-94.

Fiorentino, L.A., Olascoaga, M.J., Reniers, A., 2014. Analysis of water quality and circulation of four recreational Miami beaches through the use of Lagrangian Coherent Structures. Mar. Pollut. Bull., 83, 181-189.

Gari, S.R., Newton, A., Icely, J.D., 2015. A review of the application and evolution of the DPSIR framework with an emphasis on coastal social-ecological systems. Ocean Coast. Manag. 103, 63-77.

Grasshoff, K., Emrhardt, M., Kremling. E. K., 1983. Methods of Seawater Analysis. (2nd ed.). Verlag Chem. New York, 317p.

Hardiman, N., Burgin, S., 2010. Recreational impacts on the fauna of Australian coastal marine ecosystems. J. Environ. Manag. 91, 2096-2108.

Kjerfve, B., Lacerda, L.D., 1993. Mangroves of Brazil, in: Lacerda, L.D. (Ed.), Conservation and sustainable utilization of mangrove forest in Latin America Regions. Mangrove Ecosystems Technical Reports. No. 2, part I, pp. 245-272, 1993. 
Lin, T., Xue, X., Yi Lu, C., 2007. Analysis of Coastal Wetland Changes Using the “DPSIR” Model: A Case Study in Xiamen, China. Ocean Coast. Manag. 35, 289-303. Lozoya, J.P., Mora, J., Ariza, E., Jiménez, J.A., 2011b. A methodological framework for multi-hazard risk assessment in beaches. Environ. Sci. policy. 14, 685 - 696.

Lozoya, J.P., Sardá, R., Jiménez, J.A., 2011a. Beach Multi-Risk Assessment in the Costa Brava (Spain). J. Coast. Res. SI 61, 408-414.

Mahony, C.O., Ferreira, M., Fernandez-Palacios, Y., Cummins, V., Haroun, R., 2009. Data availability and accessibility for sustainable tourism: An assessment involving different European coastal tourism destinations. J. Coast. Res. SI 56, 1135-1139.

Nascimento, F.C. do, Lima, J.J.F., 2010. Diretrizes técnicas para locação de limites edificados em praias. Ambiente Construído. 10 (4), 197-218.

Neil, M., 2004. Microbiological Indices for total coliform and E. coli bacteria in estuarine waters. Mar. Pollut. Bull. 49, 752-760.

Neto, F.O.L., Gorayeb, A., Silva, E.V. da, Meireles, A.J.A., Filho, N.S.P., 2013. Application of the DPSIR model for the diagnosis of an estuary of the Brazilian Northeast: a tool for local and regional management. J. Coast. Res. SI65, 986-990,.

OECD, 1993. Core Set of Indicators for Environmental Performance Reviews. Organization for Economic Cooperation and Development, Paris, France, 93p.

Oliveira, S.M.O. de, Pereira, L.C.C., Vila-Concejo, A., Gorayeb, A., Sousa, R.C. de, Costa, R.M. da, 2011. Natural and anthropogenic impacts on a macrotidal sandy beach of the Brazilian Amazon (Ajuruteua): guidelines for coastal management. J. Coast. Res. SI 64, 1385-1389.

Pamplona, F.C., Paes, E.T., Nepomuceno, A., 2013. Nutrient fluctuations in the Quatipuru river: a macrotidal estuarine mangrove system in the Brazilian Amazonian basin. Estuar. Coast. Shelf Sci. 133, 273-284. 
PARÁ, $1995 . \quad$ Lei $n \quad 5.887 / 1995 . \quad$ Available in:

http://www.ideflor.pa.gov.br/file/LEl\%20N\%205.887,\%20de\%2009\%20de\%20Maio\%20d e\%201995.pdf.

Parsons, T.R., Strickland, J.D.H., 1963. Discussion of spectrophometric determination of marine-plant pigments, with revised equations for ascertaining chlorophyll-a and carotenois. J. Mar. Res. 21, 105-156.

Pereira, L. C. C., Vila-Concejo, A., Costa, R. M. da, Short, A. D. 2014a. Managing physical and anthropogenic hazards on macrotidal Amazon beaches. Ocean and Coastal Management, 96, 149-162.

Pereira, L.C.C., Pinto, K.S.T., Vila-Concejo, A., 2014b. Morphodynamic variations of a macrotidal beach (Atalaia) on the Brazilian Amazon Coast. J. Coast. Res. SI 66, 681686.

Pereira, L.C.C., Silva, N.I.S. da, Costa. R.M., Asp, N.E., Costa, K.G., da, Vila-Concejo, A., 2012. Seasonal changes in oceanographic processes at an equatorial macrotidal beach in northern Brazil. Cont Shelf Res. 43, 95-106.

Pereira, L.C.C., Oliveira, S.M. O., Costa, R.M., Costa, K.G., Vila-Concejo, A., 2013. What happens on an equatorial beach on the Amazon coast when La Nin a occurs during the rainy season? Estuar. Coast Shelf 135, 116-127.

Pereira, L.C.C., Vila-Concejo, A., Short, A. D., 2016. Coastal morphodynamic processes on the macro-tidal beaches of Pará state under tidally-modulated wave conditions, in: Short, A.D., Klein, A.H.F. (Eds.), Brazilian beach systems. Springer International Publishing. 17 of the series Coastal Research Library, pp 95-124.

Pinto, K.S.T., Pereira, L.C.C., Vila-Concejo, A., Gorayeb, A., Sousa, R.C. de, Costa, R.M. da., 2011. Effects of the lack of coastal planning on water quality and land use on a macrotidal beach (Atalaia, Pará) in the amazon region. J. Coast. Res. SI 64, 1401-1405. 
Pinto, R., Jonge, V.N. de, Neto, J.M., Domingos, T., Marques, J.C., Patrício, J., 2013. Towards a DPSIR driven integration of ecological value, water uses and ecosystem services for estuarine systems. Ocean Coast. Manag. 72, 64-79.

Praveena, S. M., Chen, K. S., Ismail, S. N. S., 2013a. Indicators of microbial beach water quality: preliminary findings from Teluk Kemang beach, Port Dickson (Malaysia). Mar. Pollut. Bull. 76, 417-419.

Praveena, S.M., Aris, A.Z. 2013b. A baseline study of tropical coastal water quality in Port Dickdon, strait of Malacca, Malaysia. Mar. Pollut. Bull. 67, 196-199.

Rovira, J., Pardo, P., 2006. Nutrient pollution of waters: eutrophication trends in European marine and coastal environments. Contributions Science. 3 (2), 181-186.

Sardá, R., Mora, J., Ariza, E., Avila, C., Jimenez, J.A., 2009. Decadal shifts in beach user sand availability on the Costa Brava (Northwestern Mediterranean Coast). Tourism Manag. 20, 393-410.

Silva, I.R., Pereira, L.C.C., Trindade, W.N., Magalhães, A., Costa, R.M., 2013. Natural and anthropogenic processes on the recreational activities in urban Amazon beaches. Ocean Coast. Manag, 76, 75-84.

Silva, N.I.S. da, Pereira, L.C.C., Vila-Concejo, A., Gorayeb, A., Sousa, R.C. de, ASP, N.E., Costa, R.M. da., 2011. Natural and social conditions of Princesa, a macrotidal sandy beach on the Amazon Coast of Brazil. J. Coast. Res. SI 64, 1979-1983.

Sousa, R. C., Pereira, L.C.C., Jiménez, J. A., 2016. Estuarine beaches of the Amazon coast: environmental and recreational characterization. J. Coast. Res. SI 70 (1), 705709.

Sousa, R.C., Pereira, L.C.C., Costa, R.A.M. da, Jimenez, J.A., 2014. Tourism carrying capacity on estuarine beaches in the Brazilian Amazon region. J. Coast. Res, SI 70, 545550. 
Sousa, R.C., Pereira, L.C.C., Costa, R.A.M. da, Jimenez, J.A., 2017. Management of estuarine beaches on the Amazon coast though the application of recreational carrying capacity indices. Tourism Manag. 59, 216-225.

Sousa, R.C., Pereira, L.C.C., Costa, R.M., 2013. Water quality at touristic beaches on the Amazon coast. J. Coast. Res, SI 65, 1057-1062.

Souza Filho, P.W.M., Tozzi, H.M., El-Robrini, M., 2003. Geomorphology, land-use and environmental hazards in Ajuruteua macrotidal sandy beach, northern Brazil. J. Coast. Res, SI 35, 580-589.

Strickland, J.D., Parsons, T.R.A., 1972. A practical Handbook of Seawater Analysis. (2th ed). J. Fish. Res. Board Can. Ottawa, 167, pp. 207-211.

Strickland, J.D.H., Parsons, T.R.A., 1968. The Practical Handbook of Seawater Analysis. J. Fish. Res. Board Can. 167, pp. 1-311.

Szlafsztein, C., 2012. Natural disasters management in the Brazilian Amazon: an analysis of the States of Acre, Amazonas and Pará, in: Sorin Cheval. (Org.). Natural Disasters. Zagreb, INTECH.

Szlafsztein, C., Sterr, H., 2007. A GIS-based vulnerability assessment of coastal natural hazard, state of Pará , Brazil. J. Coast Conserv, 11, 53-66.

UNESCO - United Nations Educational, Scientific and Cultural Organization, 1966. Determination of Photosynthetic Pigments in Sea-water. Unesco, Paris, 1-69.

UNESCO - United Nations Educational, Scientific and Cultural Organization, 1973. International Oceanographic Tables. Wormly. 2, $141 \mathrm{p.}$

Vollenweider, R.A., Giovanardi, F., Montanari, G., Rinaldi, A., 1998. Characterization of the trophic conditions of marine coastal waters, with special reference to the NW Adriatic Sea: proposal for a trophic scale, turbidity and generalized water quality index. Environmetrics. 9 (3), 329-357.

Zhang, W., Wang, J., Fan, J., Gao, D., Ju, H. Effects of rainfall on microbial water quality 
on Qingdao No. 1 Bathing Beach, China. Mar. Pollut. Bull., 66 (2013) 185-190.

\section{Figure Captions}

Figure 1. Study Area. Brazil (Left), Pará coast (Center), Murubira beach (A), Colares beach (B) and Marudá beach (C), showing water sample points and sewage outfalls.

Figure 2. Trophic status of the study beaches according to the TRIX index developed by Vollenweider et al. (1998).

Figure 3. Number of visitors on the beaches (Sousa et al., 2014), (A) Zone 1 and (B) Zone 2. 
Figure 4. Destruction of infrastructure on Murubira beach (A), Risk of drowning at Colares (B), Inadequate disposal of trash and discharge of domestic sewage at Marudá (C), Lack of zonation (motorboat and jet ski in the vicinity of bathers) at Murubira (D). Overcrowding at Marudá, zone $1(\mathrm{E})$ and Murubira, zone $2(\mathrm{~F})$.

Figure 5. Flow chart for the analysis of the study beaches. 

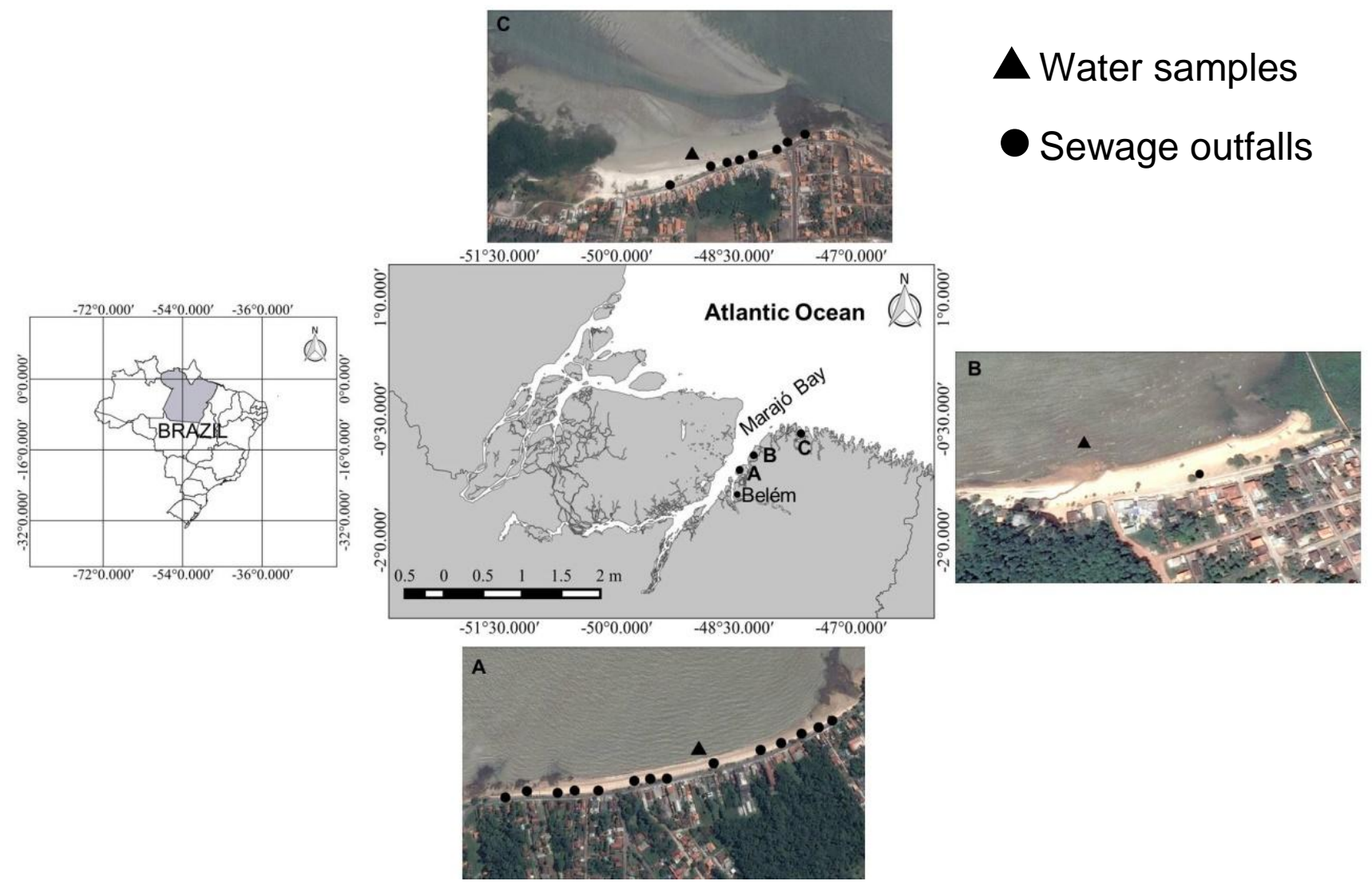

Figure 1. Study Area. Brazil (Left), Pará coast (Center), Murubira beach (A), Colares beach $(B)$ and Marudá beach $(C)$, showing water sample points and sewage outfalls. 


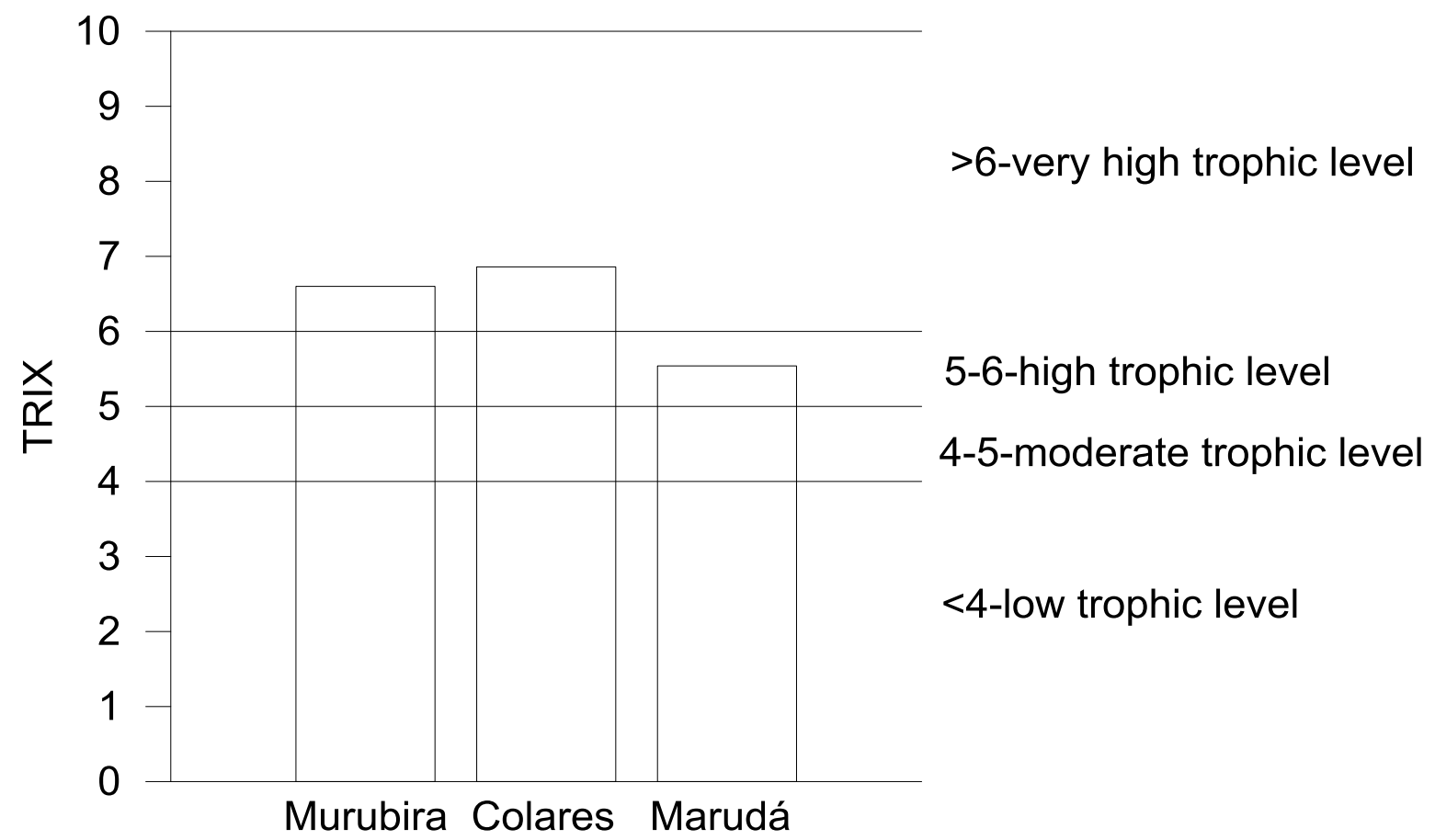

Figure 2. Trophic status of the study beaches according to the TRIX index developed by Vollenweider et al. (1998). 
Number of visitors established by Sousa et al. (2014)

Number of visitors during Sunday vacation period
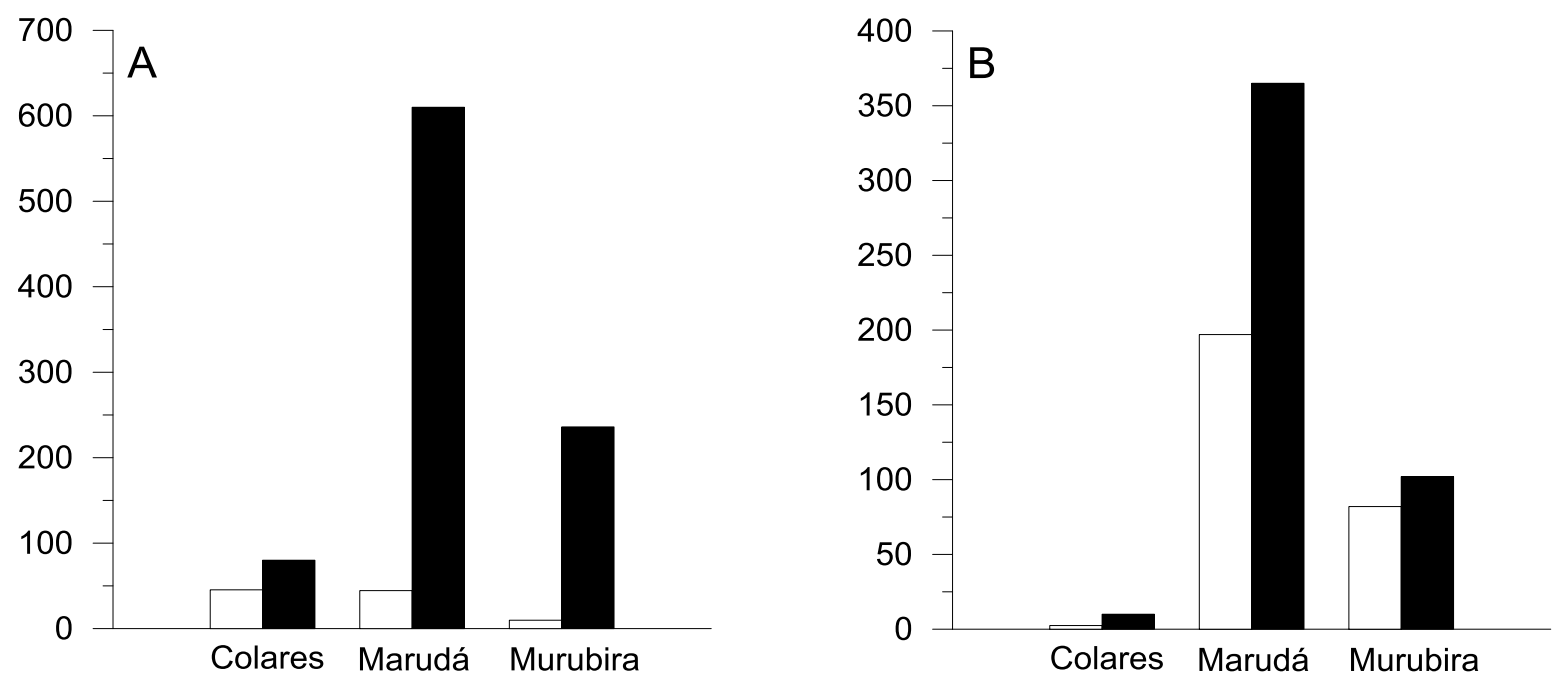

Figure 3. Number of visitors on the beaches (Sousa et al., 2014); (A) Zone 1 and (B) Zone 2. 

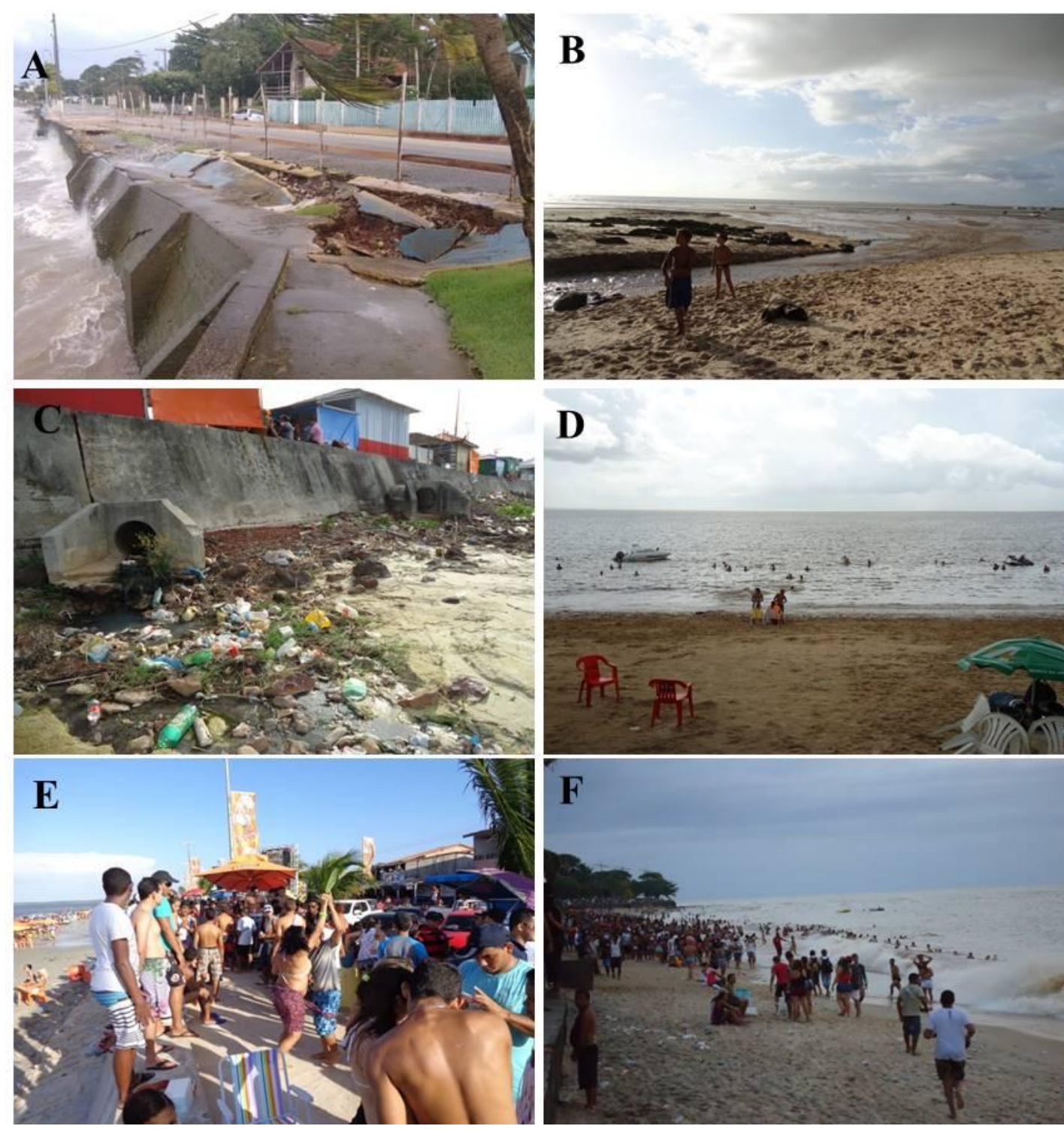

Figure 4. Destruction of infrastructure on Murubira beach (A), Risk of drowning at Colares (B), Inadequate disposal of trash and discharge of domestic sewage at Marudá (C), Lack of zonation (motorboat and jet ski in the vicinity of bathers) at Murubira (D). Overcrowding at Marudá, zone $1(\mathrm{E})$ and Murubira, zone $2(\mathrm{~F})$. 


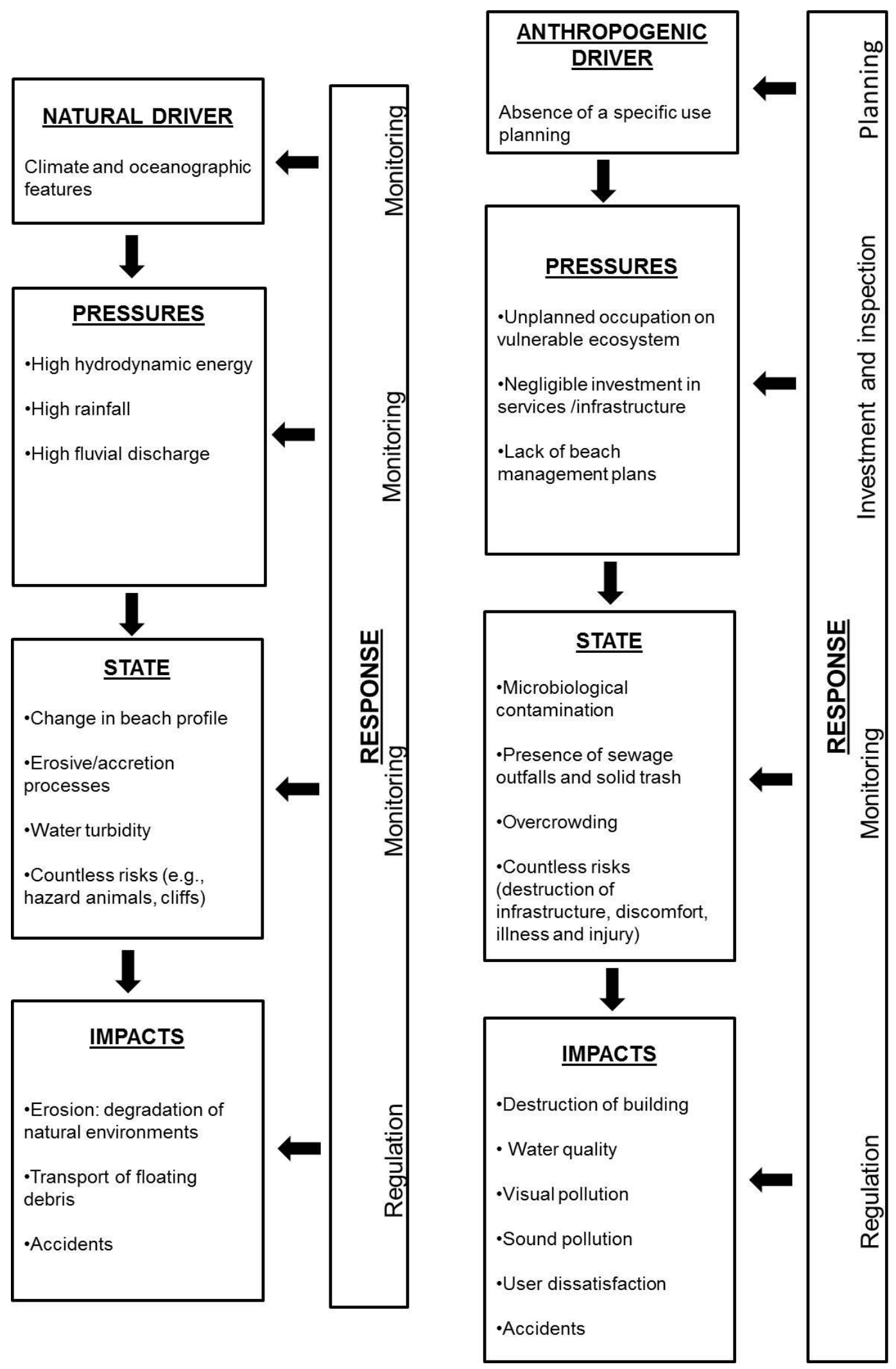

Figure 5. Flow chart for the analysis of the study beaches. 